\title{
EFFECTS OF HOME BACKGROUND ON THE ACADEMIC ACHIEVEMIENTS OF SECONDARY SCHOOL STUDENTS IN SOKOTO STATL:
}

MAYANCHI MOHAMMED LAWAL

\begin{abstract}
This study examined the effects of home background on the academic achievements of secondary school students in Sokoto State. It specifically examined the factors and influence on child performance. the efficacy of a family influence for academic success. socio-economic status of parents. the relationship between home backgromind factors and academic achievements. The research design was based on the main tenets of correlational sumey. design. The sample of the studly comprised of 195 secondar schools with a population of 2.066 students in the three senatorial districts of Sokoto Slate. The Hart Draw Method (HDM) was used in selecting wo schools from each sone. Fon hypotheses were tested for the study: The data collected for this study were subjected to chi-square tests. The findings revealed that the socio-economic status of the child's home is one of the important predicators of academic achievements in school. It was also observed that parenting styles have been associated with academic success. The following recommendation were made the need to educate parents on the need to create an educationally conducive atmosphere at home, children must be encouraged and not to be left wo the teacher alone, educators as well student-teacher who are responsible for the education of the future generations should understand what factors influence the learning and achievements of children placed in their care, while parents should provide their children with needed school matrials to stimulate intellectual development, to handle students effectively teachers should endeavor to understand their students family. background. Authoritarian and permissive methods of parenting styles should be discouraged amongst parents

\section{Introduction}

In every aspects of human endeavour there must be some underlying needs which have to be met for success to be achieved. Equally for a child to achieve academically, his/her basic needs must be provided. Research on home background factors and their influence on child performance has been conducted by educationalists and psychologists in different parts

of the globe including Nigeria. Codjoe, (2007), Eze, (2006), Ganzach, (2000); are notable examples of studies carried out on the issue of home background influence of child academic performance. Considering the dates of these studies, it is a clear testimony psychologists and educationists have for long been investigating child development in aspects of intellectual, physical, social, emotional and personality,
\end{abstract}


Effects of Home Background on the Academic Achievements of Secondary School Students In

with the aim of determining if all these aspects of development could singly or collectively have any effect on the educational achievement of school children.

Equally, Ceci (1997), propose that the efficacy of family influence on academic success is determined to a large degree by a child family background; this goes to show that there is a interrelationship between various home background factors and academic success of a child. It is against this backdrop that the researcher seeks to examine the effect of home background on academic achievement of secondary school students in Sokoto State.

\section{Statement of the Problem}

Much has been said of mass failure at all levels of Nigerias' educational, institutions. Meetings have been held, conferences and seminars have been organized as to the causes of this trend, especially in the post primary schools by the stakeholders, parents; teachers and government. Researches, have revealed that differences in academic achievement-are not solely dependent, on child's intelligence. However, factors in the home influence programmes at school in a way which was to an extent independent of intelligence. Equally where children are emotionally secure they are best able to cope with any demands that may be put on them'. Invariably low academic achievement by a learner could be linked to family dysfunction which is a fundamental aspect of children's health and well-being.

Therefore, this study was set to investigate the relationship between home-background factors and academic achievement of secondary school students in Sokoto State Academic achievement refers to knowledge and skills gained from experience, an achieved level of expertise or performance in a specific domain. It refers to the achievement by individual or objectives related to various types of knowledge and skills. These objectives are socially established based on age, prior learning and capacity of individuals regard to education, socialization and qualification.

Studies conducted on academic achievement notably focus on student progress and individual institutional and organizational factors of achievement, along with social relationship interactions to determine, facilitate or hinder academic achievement (Crires, 2005).

Socio-Economic Status of Parents

According to the evidences of sociologists, socio economic status is one of the home background 
variable that contributes to the child's success or failure in the school. Sociologists define socioeconomic status in terms of individual's income. occupation. education and prestige in society. All these factors together or combination of some has dichotomized family into social class which make students differ from one another. The higher the socio economic status of a child's parents the higher the child"s school achievement is likely to be. This scems to be the pattern from research evidence in United States, Britain. Asia and Africa - including Nigeria. A good number of researches to ascertain relationship of SES to achievement in school were consistent, Miner, (1968) cited in Uche (1980) conducted a study entitled "Some sociological background variables affecting school achievement" and found that socio-economic status of the child was related to the level of achievement. For example it was found that children of middle-class families performed better than working class families because the former live in stimulated environment. Equally, Balarabe, (1990) observed that in Nigeria secondary schools, children from middle class homes do better in school work than children from lower class, because parents from middle class are better educated and tend to hold strong pro-school values and therefore availed their children better training and experiences lor effective learning and performance in school. They have opportunity of pre-school training. alvalability of learning materials. educational toys, educitional materials, or programmes and have opportunity to speak better English which is the medium of instruction in schools. This places them to perform better than other children.

Culturally, disadvantaged homes may produce children with severe emotional stress and impoverished or impaired intellectual development. These deprivations and disturbances can leave children's abilities stunted at a level jelow their genetic potentials, while rich environmental stimulation and guidance can bring talents to a level not ordinarily reached. Other studies were also designed in the past to determine relationship between socioeconomic status and academic achievement. These includes Gbenedio, (1986); Ezeh, (1991) as well as Alexander and Sundius (1992) cited in Slavin, (2006).

Parental education influence has been identified as an important factor affecting students' academic achievement. Results indicate that parental education and encouragement are strongly related to improve student achievement.

Durojaiye, (1984) said children from elite homes are more at 
adrantige in their schooling and evell through their academic careers. In other words children lirom illiterate home background maly not have a healthy and supportive environment to bring about high academic performance. Manir, (2000) found that children from illiterate parents did worst and performed poorer than children from literate parents attending the same school. This may in other words mean that parental education and the cognitive ability of the child are probably the most important determinant of a child's academic performance.

Influence of Parenting Style or Child Rearing Practices on Academic Achievement It is assumed that the primary role of all parents is to influence, teach and control their children. Family is the traditional socializing agent and therefore parents serve as a social mirror to their children. Children in the family are at the mercy of their parents action and inaction. And hence, the type of family the child happen to be born into determine his psychological make up. A supportive home that give child a sense of belongingness and fulfill the security needs for love and affection equip the child with emotional well being and lack of it cause maladjustment like, neurocism, hostility, aggressiveness, self withdrawn, feeling of insecurity.
Sokoto State

Child rearing practices are those methods that a community or individual family applies to raise a child within that community. These methods consist of approaches that deal with the provision of such needs as adequate nutrition, shelter, physical warmth, e.g. (dressing) psychological warmth and occupational training among others. Psychosocial psychologists like Elder, (1963); Erikson, (1963); Baumrind, (1991) and Eze, (2006) shares the same opinion that parental style help to shape children's social competence. Many researchers who attempted to describe this broad parental milieu rely on Diana Baumrind's concept of parenting style. According to her the construct of parenting style is used to capture normal variations in parent's attempt to control and socialize their children Baumrind, (1991).

Maccoby and Martin (1983), who worked on parenting style and its correlates, identified two important elements of parent in: parental responsiveness and parental demandingness and base upon these two elements parents were categorized according to whether they are high or low on demandingness and responsiveness. Baumrind, (1991) parenting style typology consists of three types authoritarian, authoritative, and permissive. 
a. Authoritarian parenting style refers to child rearing techniques characteristic of harsh, disciplinary actions and rigid boundaries, expressed both emotionally and psychologically toward children. Such parents tend to be strict, harsh, punitive and demanding and tend to discourage verbal give-andtake within the family setting these parents demand obedience and beliefs that a child's will must be broken.

b. Permissive parenting style refers to child rearing practice that place few, if any, rules upon children. In extreme cases, children encounter complete. freedom to make life decision without referring to parents for advice, they come and go as they please, their where about is generally not known to their parents.

c. Authoritative parenting style refers to child rearing techniques in which parents exercise firm yet fair discipline. Despite firm discipline, parent display warmth, love and affection toward children and are "democratic" in that they participate bidirectional communication exchanges with children. Several studies carried out in the past have found that parenting styles have been associated with academic successes Eze (2006).

\section{Methodology}

This study was a correlational survey design. The justification this study was that multiple variables could be studied singly or in group in the aspect of how comparison or relationship predict students pattern of behaviour or achievement.

The population of this research comprised of students of SSII from the three Senatorial Zones in Sokoto State, was Sokoto East had 62 secondary schools, Sokoto Central had 85 secondary schools and Sokoto south had 48 secondary schools, totalling 195 secondary schools.

Six secondary schools were randomly selected from the three Senatorial Zones using two schools from each Senatorial Zone in the state. The Hat Draw Method (HDM) was used in selecting two schools from each zone. The six selected schools make up a population of 2,066 students and $20 \%$ of this was used as the sample size, going by Borg and Gall (1974) sampling procedure. Therefore, $20 \%$ of 2,066 was 411 students which was considered reasonable and was used by the researcher. A 27 items index of 
home background inventory (HB) designed by dic researcher was the instrument used in data gathering. The student continuous assessment scores in English Language and Mathematics was equally to assess the students' academic performances. The result was obtained through the assistance of Continuous Assessment and Examination Officers in the schools.

\section{Results \\ Test of Hypothesis $\mathrm{H}_{01}$}

Hypothesis $\mathrm{H}_{0 I}$, sought to establish the difference between the academic achievement of students based on their socio-economic background (that is, whether differences existed between the grades scored in Mathematics and English by students from high, middle and low income backgrounds). Chi-square test with cross tabulation was applied to the data.

The results of this test were presented in table below

Results of Chi-square test for Hypothesis $\mathrm{H}_{01}$ :

\begin{tabular}{|c|c|c|c|c|c|c|c|}
\hline \multirow{2}{*}{$\begin{array}{l}\text { Respondent } \\
411\end{array}$} & \multicolumn{2}{|l|}{ Variables } & \multirow{2}{*}{$\begin{array}{l}\text { Chi- } \\
\text { square }\end{array}$} & \multirow{2}{*}{$\begin{array}{l}\text { Critical } \\
\text { value of } \mathrm{X}^{2} \\
\text { (at } 0.5)\end{array}$} & \multirow{2}{*}{$\begin{array}{l}\text { Significance } \\
\text { value }\end{array}$} & \multirow{2}{*}{$\begin{array}{l}\text { Phi } \\
\text { value }\end{array}$} & \multirow[t]{2}{*}{ Inference } \\
\hline & $\overline{X_{1}}$ & $\mathbf{X}_{2}$ & & & & & \\
\hline 2 & $\begin{array}{l}\text { Scio- } \\
\text { economic } \\
\text { background }\end{array}$ & $\begin{array}{l}\text { Academic } \\
\text { achievement } \\
\text { in Maths }\end{array}$ & 221.31 & 2.73 & 0.000 & 0.734 & $\begin{array}{l}\text { Statistically } \\
\text { significant } \\
\text { difference }\end{array}$ \\
\hline
\end{tabular}

Source: Author's analysis of research data. (2011)

In case of the test for difference between students of high, middle and low income backgrounds with respect to their achievement in English, a Chi-square value of 221.31 was observed and compared to the critical value of 2.73 . Therefore, $\mathrm{H}_{\mathrm{s}, \mathrm{l}}$ rejected.

\section{Test of Hypothesis $\mathbf{H}_{02}$}

Hypothesis $\mathrm{H}_{02}$ sought to establish the difference between the academic achievement of students based on the size of the families the students-belonged to (that is, whether differences existed between the grades scored in Mathematics and English by students from small, medium and large and very large families).

The effect of family size on the achievement of students in English was also tested; a Chi-square value of 257.767 was observed and 
Effects of Home Background on the Academic Achieventents of Secondary. Schonl Sundents In compared to the critical value of 5.226 . Solkente Srates

The result of this test were presented in Table below:

\begin{tabular}{|c|c|c|c|c|c|c|c|}
\hline \multirow{2}{*}{$\begin{array}{l}\text { Respond } \\
\text { ent } 411\end{array}$} & \multicolumn{2}{|c|}{ Variables } & \multirow{2}{*}{$\begin{array}{l}\text { Chi- } \\
\text { squar } \\
\text { e }\end{array}$} & \multirow{2}{*}{$\begin{array}{l}\text { Critical } \\
\text { value of } \\
\mathrm{X}^{2} \quad(a t \\
0.5)\end{array}$} & \multirow{2}{*}{$\begin{array}{l}\text { Significa } \\
\text { nce value }\end{array}$} & \multirow{2}{*}{$\begin{array}{l}\text { Phi } \\
\text { valu } \\
\text { e }\end{array}$} & \multirow[t]{2}{*}{ Inference } \\
\hline & $\mathbf{X}_{1}$ & $X_{2}$ & & & & & \\
\hline 4 & $\begin{array}{l}\text { Family } \\
\text { Size }\end{array}$ & $\begin{array}{l}\text { Academic } \\
\text { achievemen } \\
t \text { in English }\end{array}$ & $\begin{array}{l}257.7 \\
67\end{array}$ & 5.226 & 0.000 & $\begin{array}{l}0.79 \\
2\end{array}$ & $\begin{array}{l}\text { Stutistically } \\
\text { significant } \\
\text { difference }\end{array}$ \\
\hline
\end{tabular}

Source: $\quad$ Author's analysis of research data. (20I I)

The effect of family size on the achievement of students in English was also tested; a Chi-square value of 257.767 was observed and compared to the critical value of 5.226. Therefore, $\mathrm{H}_{02}$ rejected.

\section{Test of Hypothesis $\mathrm{H}_{03}$}

Hypothesis $\mathrm{H}_{0} 3$ was formulated to test differences in the academic achievement of students with different parenting backgrounds (that is, whether differences existed between the grades scored in Mathematics and English by students whose parents practiced different styles of parenting).

The results of this test were presented in Table below.

Results of Chi-square test for Hypothesis $\mathrm{H}_{03}$

\begin{tabular}{|c|c|c|c|c|c|c|c|}
\hline \multirow{2}{*}{$\begin{array}{l}\text { Respondent } \\
\text { s } 411\end{array}$} & \multicolumn{2}{|c|}{ Variables } & \multirow{2}{*}{$\begin{array}{l}\text { Chi- } \\
\text { square }\end{array}$} & \multirow{2}{*}{\begin{tabular}{l}
\multicolumn{2}{l}{ Critical } \\
value of \\
$\mathrm{X}^{2} \quad(a t$ \\
$0.5)$
\end{tabular}} & \multirow{2}{*}{$\begin{array}{l}\text { Significan } \\
\text { ce value }\end{array}$} & \multirow{2}{*}{$\begin{array}{l}\text { Phi } \\
\text { valu } \\
\text { e }\end{array}$} & \multirow[t]{2}{*}{ Inference } \\
\hline & $\mathbf{X}_{1}$ & $\overline{X_{2}}$ & & & & & \\
\hline 6 & $\begin{array}{l}\text { Parental } \\
\text { style }\end{array}$ & $\begin{array}{l}\text { Academic } \\
\text { achievemen } \\
t \text { in English }\end{array}$ & 221.31 & 2.73 & 0.000 & $\begin{array}{l}0.00 \\
0\end{array}$ & $\begin{array}{l}\text { Statistically } \\
\text { significant } \\
\text { difference }\end{array}$ \\
\hline
\end{tabular}

Source: $\quad$ Author's analysis of research data, (2011)

In the case of the test for differences in academic performance in English with respect to the parenting backgrounds of the students, a chisquare value of 221.31 was observed and compared to the critical value of 2.73 . Therefore, $\mathrm{H}_{\mathrm{o3}}$ rejected.

\section{Discussion of Results}

In testing for statistical correlation for hypothesis I, it was discovered that differences existed between the grade scored in Mathematic and English by students from high, 


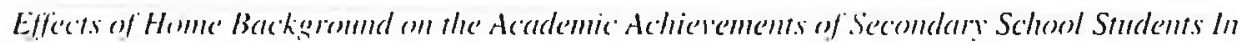

midule and low income

backgeromel. In Mathematics. the

Chi-syuare value of 15.729 was

observed which is graater than the

critical value of 2.73. In the case of

correlation belween students of

high. middle and low income

background with respect to their

achievement in English. a chi-

square value of 221.31 was

observed-which is far greater than

the critical value of 2.73. Thus, it

was concluded that socio-economic background had a large effect on the academic achievement of students more especially in English. However, the influence of socio-economic status in Mathematics was small.

The general analysis has shown that the socio-economic status of the child home was one of the important predicators of academic achievement in school. Children from higher socio-economic home achieved higher in school than those of the lower socio-economic background. This finding was in line with the findings of Sheikh (1996). His finding revealed that "children from modern Hausa homes because they are provided with play materials, watch television, receive parental assistance and encouragement were superior intellectually compared to those children from traditional home where parental stimulation and provision of learning material and relevant material were lacking. These children tend to experience slow intellectual growth." Similarly. Gbenedio (1986). Slavin, (2006). and Bitture, (2006) research findings supported the finding of the study.

In testing for statistical correlation for hypothesis II, it was discovered that differences existed between the grades scored in Mathematic and English by students from small, medium and large and very large families. In Mathematics Chisquare value of 23.653 was observed which was greater than critical value of 5.226 .

In the case of correlation between family sizes on the achievement of students in English, a Chi-square value of 257.767 was observed which is far greater than the critical value of 5.226. Thus, it was concluded that there is significant relationship between family size and academic achievement of SS II students from the analysis of the result. It was apparent that children from larger family obtained more "E" and "D" grades than students from smaller families. This finding was in line with the finding of Awoyemi (1986), who found that there is a significant relationship between the number of people in the family and student academic performance.

In testing for statistical correlation for hypothesis three (3) it was discovered that difference existed 
between the grade scored in Mathematic and English by SS II students with different parenting backgrounds (i.e. democratic, autocratic, permissive). In mathematics, a Chi-square value of 15.759 was observed which was greater than critical value of 2.73 . In case of correlation of test for difference in academic achievement in English with respect to parenting background of the students, a Chi-square value of 221.31 was observed which was greater than critical value of 2.73 . Thus, it can be concluded that there is significant difference between the parenting styles and academic achievement of SS II students.

This finding confirmed the findings of Dorbusch et el (1987), Lamborn et al. (1991). Whose finding revealed that parenting styles have been associated with academic success. Most specifically Authoritarian and permissive parenting style have been associated with poor academic grade.

\section{Conclusions}

Home background variables have been investigated by developmental psychologists because of its effect on child developmental processes in term of child social, instrumental competence and achievement. The current study found that variable such as socio-economic status, family size and parenting sol have effect on academi. achievement on SSII students.

I

The findings reported in this study in terms of children from different socio-economic class is significantly related with academic achievement. Children from high socio-economic background achieve better in English than children from low socioeconomic background. Equally, grades scored in Mathematics by students from high, middle and low income background differed significantly from what could be explained as being due to chance alone.

\section{Recommendations}

From the finding of this study, the following recommendations are made:

1. There is need to educate parents on the need to create an educationally conducive atmosphere at home children must be encouraged and not to be left to the teacher alone.

2. Educators as well as student-teacher who are responsible for the education of the future generation should understand what factors influence the learning and achievement of children placed in their care, while parents should provide their 
Effects of Home Background on the Academic Achierements of Secondary School Students In Sokomo Stare

children with needed school materials to stimulate intellectual development.

3. To handle students effectively teachers should endeavor to understand their students family background.

4. From this study, Authoritarian and permissive methods of parenting practices should be discouraged among parents.

\section{References}

Adeniyi, E. F. (2001). "Parenting influence on child psychological development, challenges for guidance", A.B.U Journal of counseling and human development, 1 (1).

Awoyemi, O. M. (1986). Some intra-family Variations and their Bearings upon Students Achievement. The case of the Institute of Education, University of Ilorin, 1984 Summer School Students. Nigeria Educational Forum, 9 (2): 193-199.

Balarabe, M. (1990). Home background influences on pupils' motivation, Attitudes and academic Achievement in Nigeria secondary schools Zaria Journal of Studies in
Education A.B.U. Zaria. 1 (1): $111-112$.

Baumrind, D. (1991). The Influence of Parenting Style on Adolescent Competence and Substance Use. Journal of Early Adolescence, 11 (1): 56-95.

Ceci, J. S. (1997). Family background and Family structure. Retrieved September $4^{\text {th }}$ '2008 from http://Family.grank.org/pages /ll/academic__achievement family-Background-Family structure html.

Codjoe, M. H. (2007). The importance of home environment and parental encouragement in the Academic Achievement of African Canadian Youth: Canadian Journal of Education, 30 (1): 137-156.

Crires, (2005). Documentary watch Retrieved November, $11^{\text {th }}$ 2008 from htp://www. criresoirs.ulaval.ca/sgc/lang/enca/p id/549.'

Dorbush, S. M.; Ritter, P. L.; Leiderman, P. H.; Robert, D. F. \& Fraleigh, M. J. (1937). The Relation of Parenting Style to Adolescent School Performance.

Child

Development, 58: 244-257. 
Diguilio. R. C. (1986). Effective parenting: what is your sty/e." Chicago. Follot Publishing Company.

Durojaiye, M. O. A. (1984). A new introduction to educational psychology. Ibadan: Evans brothers Nigeria publishing company.

Elder, G. H. (1963). Parent power legitimation and it effect on adolescent Sociometry 26: 50-65.

Erickson E. H. (1963); Childhood and society New York: Norton.

Eze, U. J. (2006). Effects of parenting styles on academic performance of secondary school students in Cross River State. Joumal of Educational Improvement, 3: 24-31.

Ezeh, H. O. (1991). Mathematics Achievement Related to Parental Socio-Eiconomic Status and Pupils Sex. Nigeria Education Forum, 13: $153-156$

Ganzach, Y. (2000). Parent education, cognitive ability, educational expectations and educational attainment: Interactions effects Britis/l Journal of Educational psychology. 70: $419-449$.
Gbennedio, B. U. (1986). The effect of socio-economic background on academic achievement in reading: Nigeria Educational Joumal. 9 (1): 83-84.

Gerda, \& Dennis, U. (1980). Educational psychology in a changing -world.

Gutheris, C. A.; Urberge, T. G. \& Turbiville, P. V. (2003). Fathers involvement in program for young children in Annals Editions Early childhood $23 \mathrm{Ed}$.

Hickman, \& Gregory, P. Barthhome, Suzanne, Mikeriry, \& Patrick, (2006). Adjustment and academic achievement of traditional college Freshman Journal of College of student development Retrieved November $11^{\text {th }} 2008$ from http://fmclarticles:com/p/artic les/m/-aa3752/is-20000 i/ai A8892466.

Inguile, O. F.; Rono, C. R. \& Ndambuki, W. P. (1996). Introduction to Educational psychology. Nairobi: Kenya English press Lid.

Isah; A. M. (2004). Parental attitude towards cognitive development of children among the Hausa in U. T. 
Effects of Home Background on the Academic Achievements of Secondary School Sundents In

Mohammed: A. A. Salawu: G. V. Ardo, \& M. G. Dukku. (eds.). Educational Themes in Nigeria, (p 8-16) Kaduna: Nasara Press Ltd.

Lamb, M. E. (1981). The role of the father in child development 2 Ed New York: Wiley.

Maccoby, \& Martins, (1983). Parenting style \& correlates retrieved November $21^{\mathrm{st}} / 2008$ from

http://www.athealth.com/prac titioner/educ/parenting $\underline{\text { styles.html }}$

Magdol, L. (1994) Risk factor for adolescence academic achievement, Retrieved from http://www.cyfernet.mes.umn .ecluc/research/youthfut 3. htm 1. Maitafsir, M.G. (2002). Thesis Writing in Education: An Illustration. Sokoto: Milestone.

Manir, R. A. (2000). Influence of Home, Preschool Experience in Children Motivation and Academic Achievement. Unpublished Master's Thesis, Ahmadu Bello University Zaria, Nigeria.

Musgrave, (1979). The Sociology of Education, London. Methun.

Qbeta, I. C. (2005). Relationship between home
Sokoro Siate

environment/personality and academic achievement of Shehu Shagari College of Education student. Unpublished M.Ed. Dissertation, UDUS.

Slavin, R. E. (2006). Educational Psychology; Theory and Practice 8 (Ed) USA: Pearson Education.

Uche, W. U. (1980). Sociology of Education for NCE Students. London: George Allen \& Irwin. 